\title{
TERCAPAINYA TINGKAT EFEKTIVITAS WAKAF UANG UNTUK MEMBERDAYAKAN KESEJAHTERAAN MAUQUF 'ALAIH DI YAYASAN DANA SOSIAL AL FALAH (YDSF) SURABAYA')
}

\author{
Astrianisa Fathona \\ Program Studi S1 Ekonomi Islam_Fakultas Ekonomi dan Bisnis-Universitas Airlangga \\ Email: achieniesa@gmail.com \\ Moh. Qudsi Fauzi \\ Departemen Ekonomi Syariah-Fakultas Ekonomi dan Bisnis-Universitas Airlangga \\ Email: qudsifauzyl@gmail.com
}

\begin{abstract}
:
As finance instrument, cash waqf becomes brand new in history of Islamic banking. Waqf is an act of worship by separating personal wealth to be public wealth in order to embody people prosperity. This research uses a qualitative approach with case study method. Data collection is conducted by interviewing informan (nazhir, wakif, and mauquf 'alaih). The technique of analysis used in this study is reduce, present, and conclude the result. Then, the technique of data validity is source triangulation. The result of the study is the effectiveness of cash waqf's program to distribute the fund to build a mosque. The level of effectiveness would be successful if all the element were totally accomplished and also affect people prosperity in maqashid syariah's perspective.
\end{abstract}

Keywords: Effectiveness, Cash Waqf, Empowerment, Prosperity

\section{Pendahuluan}

Pengertian wakaf menurut hukum Islam berarti menyerahkan suatu hak milik yang tahan lama kepada seseorang atau nadzir baik berupa perorangan maupun lembaga, dengan ketentuan bahwa hasilnya digunakan sesuai dengan syariat Islam.Harta yang telah diwakafkan keluar dari hak milik wakif dan bukan pula hak milik nadzir/lembaga pengelola wakaf tapi menjadi hak milik Allah yang harus dimanfaatkan untuk kesejahteraan mavquf 'alaih.Islam sangat menganjurkan praktek perwakafan karena dapat membantu rakyat yang kurang mampu, bahkan praktek perwakafan juga dapat menjadi modal untuk kelembagaan dalam bidang pendidikan serta membangun perpustakaan.
Wakaf seringkali diartikan sebagai aset yang dialokasikan untuk kemanfaatan umat di mana substansi atau pokoknya ditahan (Antonio, 2006:3).Sedangkan menurut Mustafa AsSiba'i dan Muhsin (2004) membagi wakaf menjadi dua macam, yang pertama adalah wakaf dalam lingkungan keluarga (dzurri) dan yang kedua adalah wakaf untuk lingkungan masyarakat umum (khairi).Wakaf yang pertama adalah harta yang dikhususkan untuk orang-orang tertentu yang digunakan untuk kegiatan yang baik untuk lingkungan keluarga, sedangkan untuk wakaf yang kedua adalah harta yang digunakan untuk kepentingan masyarakat umum.

\footnotetext{
1) Jurnal ini merupakan bagian dari skripsi dari Astrianisa Fathona, NIM : 041114168 , yang diuji pada 10 Februari 2016
} 
Fathona, et al/Jurnal Ekonomi Syariah Teori dan Terapan Vol. 3 No. 1 Januari 2016: 56-69; TERCAPAINYA TINGKAT EFEKTIVITAS WAKAF UANG UNTUK MEMBERDAYAKAN KESEJAHTERAAN MAUQUF 'ALAIH DI YAYASAN DANA SOSIAL AL FALAH (YDSF) SURABAYA

Wakaf yang berarti ibadah maliyah ijtima'iyyah (ibadah harta untuk kesejahteraan masyarakat) memiliki peran penting dan sangat menentukan untuk pembangunan kesejahteraan umat.Akan tetapi, manfaat wakaf kurang dipergunakan secara optimal supaya dapat meningkatkan kualitas kehidupan masyarakat di Indonesia. Kendala di antaranya adalah (Anshori, 2005:97) :

a. Wakaf hanya dipahami sebagai bentuk barang yang tidak bergerak, contohnya tanah dan bangunan.

b. Belum optimalnya lembaga-lembaga pengelola wakaf (nadzir) dalam mengelola wakaf yang seharusnya lembaga tersebut dapat membantu pemanfaatan harta wakaf lalu dapat digunakan dalam bentuk produktif, contohnya upaya meningkatkan usaha mikro kecil.

c. Belum maksimalnya sosialisasi pelaksanaan wakaf vang kepada masyarakat.

Di Indonesia, wakaf telah dikenal dan dilaksanakan oleh umat Islam sejak agama Islam masuk di Indonesia. Sebagai salah satu institusi keagamaan yang erat hubungannya dengan sosial ekonomi, wakaf telah banyak membantu pembangunan secara menyeluruh di Indonesia baik dalam pembangunan sumber daya manusia maupun dalam pembangunan sumber daya sosial.Tak dapat dipungkiri bahwa sebagian besar rumah ibadah, perguruan Islam dan lembaga-lembaga keagamaan Islam lainnya dibangun di atas tanah wakaf.Karena itulah pelaksanaan wakaf di Indonesia masih jauh tertinggal dibandingkan dengan pelaksanaan wakaf di negara-negara Islam lainnya.Badan yang membidani secara khusus, yaitu Badan Wakaf Indonesia (BWI) tugasnya mengelola dan memajukan perwakafan di Indonesia, sebagaimana yang diamanatkan pasal 47, UU No 41 tahun 2004.

Praktek wakaf vang di Indonesia mulai dikenal setelah dikeluarkannya fatwa Majelis Ulama Indonesia (MUI) tanggal 11 Mei 2002 tentang wakaf dan diperkuat dengan Undang-Undang Nomor 41 Tahun 2004 tentang wakaf dan peraturan pemerintah Nomor 42 Tahun 2006 tentang pelaksanaan UndangUndang Nomor 41 Tahun 2004 serta yang paling baru adalah peraturan menteri agama RI Nomor 4 Tahun 2009 tentang administrasi pendaftaran wakaf vang. Peraturan perundang-undangan tersebut mengatur bentuk benda wakaf antara benda tidak bergerak, benda bergerak, dan vang. Hal ini dapat dilihat dalam ketentuan yang terdapat dalam Pasal 28 s.d 31 Undang-Undang Nomor 41 Tahun 2004 dan Pasal 22 s.d 27 peraturan pemerintah Nomor 42 Tahun 2006 (Lubis, 2010:107).

Ayat Al Qur'an yang menjelaskan tentang saling memberikan sebagian harta (nafkah) diantaranya adalah Q.S Al Baqarah [2]:261 yang berbunyi:

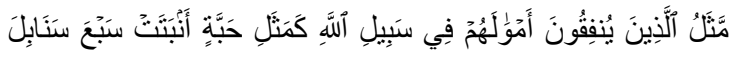

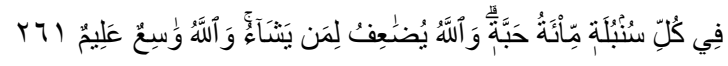
"Perumpamaan (nafkah yang dikeluarkan oleh) orang-orang yang menafkahkan hartanya di jalan Allah adalah serupa dengan sebutir benih yang menumbuhkan tujuh bulir, pada tiap-tiap 
Fathona, et al/Jurnal Ekonomi Syariah Teori dan Terapan Vol. 3 No. 1 Januari 2016: 56-69; TERCAPAINYA TINGKAT EFEKTIVITAS WAKAF UANG UNTUK MEMBERDAYAKAN KESEJAHTERAAN MAUQUF 'ALAIH DI YAYASAN DANA SOSIAL AL FALAH (YDSF) SURABAYA

bulir seratus biji.Allah melipat gandakan (ganjaran) bagi siapa yang Dia kehendaki.Dan Allah Maha Luas (karuniaNya) lagi Maha Mengetahui." (Q.S Al Baqarah [2]:261). (Depag RI 2009).

Efektivitas wakaf uang pada suatu lembaga wakaf dalam hal ini menjadi satu hal yang dapat mensejahterakan bagi masyarakat ekonomi lemah. Apabila efektivitas wakaf uang tersebut dapat dicapai maka akan berdampak positif bagi mauquf 'alaih.Efektivitas disini menunjukkan keberhasilan dari segi tercapai atau tidaknya sasaran yang telah ditetapkan. Jika hasil dari wakaf vang yang dapat mensejahterakan masyarakat semakin mendekati sasaran maka akan semakin tinggi efektivitasnya.

Yayasan Dana Sosial Al Falah (YDSF) Surabaya adalah salah satu yang memanfaatkan wakaf vang serta memiliki program-program unggul untuk dapat membantu masyarakat yang mengalami kesusahan dan sebagai umat manusia kita harus saling tolong menolong antar sesama. Untuk program wakaf uang sudah dikelola oleh lembaga yang professional dan akan terus mengembangkan wakaf uang tersebut. Yayasan ini sudah berdiri sejak tahun 1987 dan semakin tahun akan bertambah dan memiliki cabang di seluruh Indonesia, tidak terkecuali untuk kota kecil. Hal ini terbukti dengan menyebarnya YDSF pada 25 provinsi di seluruh wilayah Indonesia.

Penelitian ini dibuat untuk mengetahui bagaimanakah efektivitas program wakaf uang dalam pemberdayaan kesejahteraan mauquf 'alaihpada Yayasan Dana Sosial Al Falah (YDSF) Surabaya.

\section{Landasan Teori}

Wakaf merupakan bentuk ibadah yang dilakukan dengan memisahkan harta milik pribadi untuk dijadikan harta milik umum. Berdasarkan maknanya yang umum, wakaf memberikan harta atau pokok benda yang produktif terlepas dari campur tangan pribadi, menyalurkan hasil dan manfaatnya secara khusus sesuai dengan tujuan wakaf, baik untuk kepentingan perorangan, nazhir, agama atau umum (Qahaf: 2007). Beberapa ayat yang memerintahkan manusia berbuat baik untuk kebaikan masyarakat dipandang oleh para ahli sebagai landasan perwakafan seperti dalam Q.S Al Imran [3]:92, ayat tersebut berbunyi:

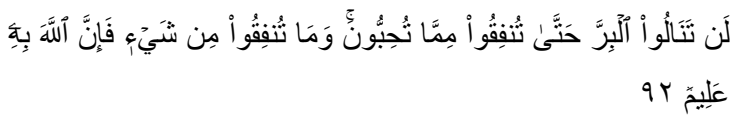

"Kamu sekali-kali tidak sampai kepada kebajikan (yang sempurna), sebelum kamumenafkahkan sehahagian harta yang kamu cintai.Dan apa saja yang kamu nafkah-kan maka sesungguhnya Allah mengetahuinya." (Q.S Al Imran [3]:92).

Sumber hukum Islam yang utama adalah berasal dari Al Qur'an dan As Sunnah, maka dari itu kita sebagai umat manusia dianjurkan untuk menjalankan perintah-Nya dan menjauhi larangan-Nya. Seperti apa Q.S Al Hajj [22]:77 yang berbunyi:

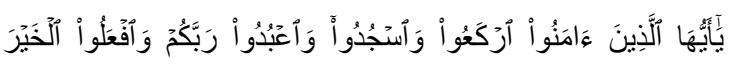

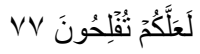

"Hai orang-orang yang beriman, ruku'lah kamu, sujudlah kamu, sembahlah 
Fathona, et al/Jurnal Ekonomi Syariah Teori dan Terapan Vol. 3 No. 1 Januari 2016: 56-69; TERCAPAINYA TINGKAT EFEKTIVITAS WAKAF UANG UNTUK MEMBERDAYAKAN KESEJAHTERAAN MAUQUF 'ALAIH DI YAYASAN DANA SOSIAL AL FALAH (YDSF) SURABAYA

Tuhanmu dan perbuatlah kebajikan, supaya kamu mendapat kemenangan". (Q.S Al Hajj [22]:77).

Jenis-jenis wakaf berdasar peruntukan dibagi menjadi dua macam, yaitu wakaf ahli (dzurri) dan wakaf kebajikan (khairi) (Sabiq 1971: 378):

1. Wakaf ahli (Dzurri)

Disebut juga Alal Aulad.Wakaf ini adalah wakaf yang dikhususkan bagi orang-orang tertentu, dalam seorang ataupun lebih, baik ada ikatan keluarga ataupun tidak serta harus ditujukan untuk kegiatan yang baik untuk kepentingan lingkungan keluarga.Secara hukum, wakaf Dzurri dibenarkan tetapi pada perkembangan berikutnya wakaf ini dianggap kurang memberikan manfaat secara umum karena sering menimbulkan kekaburan dalam pengelolaan serta pemanfaatan oleh keluarga yang diserahi harta wakaf tersebut.

2. Wakaf kebajikan (Khairi)

Wakaf yang sejak semula ditujukan untuk kepentingan umum, tidak dikhususkan untuk orang-orang tertentu. Definisi ini berdasarkan hadis Umar bin Khattab tentang wakaf. Yang dimaksud kepentingan umum adalah sudah mencakup siapapun yang termasuk golongan fakir miskin.

Jenis-jenis wakaf berdasarkan jenis harta adalah (Asy Syarbini, 1958: 240):

1. Benda tidak bergerak (tanah, sawah, dan bangunan)

Benda jenis inilah yang sangat dianjurkan agar diwakafkan, karena mempunyai nilai jariyah yang lebih lama. Ini sejalan dengan praktek wakaf yang dilakukan oleh sahabat Umar ibn Khattob atas tanah khaibar atas perintah Rasulullah SAW. Demikian juga yang dilakukan oleh Bani al Najjar yang mewakafkan bangunan dan dinding pagarnya kepada Rasul untuk kepentingan masjid.

2. Benda bergerak (binatang ternak, logam mulia, surat berharga, kendaraan, hak atas kekayaan intelektual, dan hak sewa).

Jenis ini dapat juga

diwakafkan.Namun demikian nilai

jariahnya terbatas hingga benda-benda tersebut dapat

dipertahankan.Bagaimanapun juga, apabila benda-benda itu tidak dapat lagi dipertahankan keberadaanya maka selesailah wakaf tersebut. Kecuali apabila masih memungkinkan diupayakan untuk ditukar atau diganti dengan benda baru yang lain. Sementara ulama ada yang membagi benda wakaf kepada benda yang berbentuk masjid dan bukan masjid, yang berbentuk masjid jelas termasuk benda yang tidak bergerak.

Selintas wakaf vang ini memang tampak seperti instrumen keuangan Islam lainnya yaitu zakat, infaq, sedekah (ZIS).Padahal ada perbedaan antara instrumen-instrumen keuangan tersebut. Berbeda dengan wakaf uang, zakat adalah nama bagi sejumlah harta tertentu yang telah mencapai syarat tertentu yang diwajibkan oleh Allah untuk dikeluarkan dan diberikan kepada yang berhak menerimanya dengan persyaratan tertentu pula; infaq berarti mengeluarkan sebagian dari harta atau pendapatan/penghasilan untuk suatu kepentingan yang diperintahkan ajaran Islam; sedekah sama dengan pengertian infaq, termasuk juga hukum dan ketentuan-ketentuannya, hanya saja infaq berkaitan dengan materi, sedekah memiliki arti lebih luas, menyangkut hal 
Fathona, et al/Jurnal Ekonomi Syariah Teori dan Terapan Vol. 3 No. 1 Januari 2016: 56-69; TERCAPAINYA TINGKAT EFEKTIVITAS WAKAF UANG UNTUK MEMBERDAYAKAN KESEJAHTERAAN MAUQUF 'ALAIH DI YAYASAN DANA SOSIAL AL FALAH (YDSF) SURABAYA

yang bersifat non materiil; sementara pada wakaf uang, uang pokoknya akan diinvestasikan terus-menerus sehingga umat memiliki dana yang selalu ada dan akan bertambah seiring bertambahnya jumlah wakif yang beramal, kemudian keuntungan investasi dari pokok itulah yang akan mendanai kebutuhan rakyat miskin. Oleh karena itu, instrumen wakaf vang dapat melengkapi ZIS sebagai instrumen penggalangan dana masyarakat.

Secara ekonomi, wakaf uang ini sangat besar potensinya untuk dikembangkan karena dengan model wakaf uang ini daya jangkau serta mobilisasinya akan jauh lebih merata di tengah-tengah masyarakat dibandingkan dengan model wakaf tradisional (wakaf dalam bentuk tanah dan bangunan). Sebab wakaf dalam bentuk tanah dan bangunan hanya dapat dilakukan oleh kelvarga atau individu yang terbilang mampu.Wakaf seperti ini adalah wakaf produktif dalam arti mendatangkan aspek ekonomi dan kesejahteraan masyarakat.Ironinya, di Indonesia banyak pemahaman masyarakat yang mengasumsikan wakaf adalah lahan yang tidak produktif bahkan mati yang perlu biaya dari masyarakat seperti kuburan, masjid dan lain-lain.

Namun wakaf uang ini merupakan implementasi produk baru dalam sejarah perekonomian Islam yang dipelopori oleh Muhammad Abdul Mannan, di Bangladesh.Wakaf vang mendapat perhatian serius karena memiliki akar panjang dalam sejarah Islam.Sebagai instrumen keuangan, wakaf vang merupakan produk baru dalam sejarah perbankan Islam.Pemanfaatan wakaf uang yang dipelopori Mannan dibedakan menjadi dua, yaitu pengadaan barang privat dan barang sosial.Karena itu wakaf vang membuka peluang yang unik bagi penciptaan investasi di bidang keagamaan, pendidikan dan pelayanan sosial.Tabungan dari warga yang berpenghasilan tinggi dapat dimanfaatkan melalui penukaran sertifikat wakaf vang.

Wakaf uang ini termasuk salah satu wakaf produktif.Ahli zakat KH.Didin Hafidhuddin menjelaskan bahwa wakaf produktif merupakan pemberian dalam bentuk sesuatu yang bisa diusahakan atau digulirkan untuk kebaikan dan kemaslahatan umat. Maka ada 4 (empat) manfaat wakaf vang, diantaranya ialah (Anshori, 2005:97):

1. Jumlah dari wakaf uang dapat bermacam-macam sehingga seseorang yang memiliki dana terbatas sudah bisa mulai memberikan dana wakafnya tanpa harus menunggu menjadi tuan rumah terlebih dahulu.

2. Dana wakaf uang juga bisa membantu sebagian lembagalembaga pendidikan Islam yang cash flow-nya terkadang naik turun.

3. Aset wakaf berupa tanah kosong bisa mulai dimanfaatkan dengan pembangunan gedung atau diolah untuk lahan pertanian.

4. Untuk kedepannya, umat Islam dapat mandiri dalam mengembangkan dunia pendidikan tanpa tergantung 
Fathona, et al/Jurnal Ekonomi Syariah Teori dan Terapan Vol. 3 No. 1 Januari 2016: 56-69; TERCAPAINYA TINGKAT EFEKTIVITAS WAKAF UANG UNTUK MEMBERDAYAKAN KESEJAHTERAAN MAUQUF 'ALAIH DI YAYASAN DANA SOSIAL AL FALAH (YDSF) SURABAYA

pada anggaran pendidikan negara yang semakin lama semakin terbatas.

Sebagai negara yang memiliki penduduk mayoritasnya Muslim, UndangUndang No.41 Tahun 2004 tentang wakaf ini sering diklaim sebagai regulasi yang mengatur wakaf produktif di Indonesia. Pada Pasal 15 sampai Pasal 22 UndangUndang Wakaf diatur dalam perluasan obyek wakaf yang tidak hanya berbentuk wakaf tidak bergerak seperti tanah tetapi juga berupa harta tidak bergerak, termasuk wakaf uang atau wakaf uang lainnya.Dalam Pasal 22 UU Wakaf, tujuan dan fungsi wakaf hanya dapat diperuntukkan bagi; (a) Sarana dan kegiatan peribadatan; (b) Sarana dan kegiatan pendidikan serta kesehatan; (c) Bantuan kepada fakir miskin anak terlantar, yaitu piatu, beasiswa; (d) Kemajuan dan peningkatan ekonomi umat dan; (e) Kemajuan kesejahteraan umum lainnya yang tidak bertentangan dengan syariat dan peraturan perundang-undangan. $\mathrm{Hal}$ itu memungkinkan pengelolaan harta benda wakaf dapat memasuki wilayah kegiatan ekonomi secara luas, sepanjang pengelolaan tersebut sesuai dengan prinsip manajemen dan ekonomi syariah.

Potensi dari wakaf vang sangat besar jika mampu dikelola secara baik. Terutama jika dana itu diserahkan kepada pengelola profesional dan diinvestasikan di sektor yang produktif sehingga dana tersebut dapat digunakan untuk kegiatan ekonomi produktif dalam rangka membantu kaum dhuafa dan kepentingan umat. Adapun keunggulan dari wakaf vang diantaranya ialah (Anshori, 2005:97):

1. Wakaf uang lebih produktif

Kelebihan wakaf vang yang lain adalah lebih produktif, dananya langsung dapat dimanfaatkan, hasil investasi dana wakaf langsung dapat dipergunakan untuk kemaslahatan umat.

2. Keunggulan lainnya

Wakaf uang dapat dipergunakan untuk mendanai dan mengembangkan harta wakaf berupa tanah dan bangunan untuk kepentingan usaha produktif.Seperti membangun pertokoan, kedai, swalayan, rumah sakit, dan sebagainya.

3. Lebih mudah dilaksanakan oleh wakif Karena wakaf uang dapat diamalkan oleh siapa saja tanpa menunggu kaya terlebih dahulu. Dengan kata lain dapat diamalkan sesuai dengan kemampuan ekonomi seseorang, juga dapat diamalkan dengan berjamaah ataupun berkelompok.

Wakaf uang ini termasuk salah satu wakaf produktif.Ahli zakat KH.Didin Hafidhuddin menjelaskan bahwa wakaf produktif merupakan pemberian dalam bentuk sesuatu yang bisa diusahakan atau digulirkan untuk kebaikan dan kemaslahatan umat. Maka ada 4 (empat) manfaat wakaf vang, diantaranya ialah (Anshori, 2005:97):

1. Jumlah dari wakaf uang dapat bermacam-macam sehingga seseorang yang memiliki dana terbatas sudah bisa mulai memberikan dana wakafnya tanpa harus menunggu menjadi tuan rumah terlebih dahulu.

2. Dana wakaf uang juga bisa membantu sebagian lembagalembaga pendidikan Islam yang cash flow-nya terkadang naik turun. 
Fathona, et al/Jurnal Ekonomi Syariah Teori dan Terapan Vol. 3 No. 1 Januari 2016: 56-69; TERCAPAINYA TINGKAT EFEKTIVITAS WAKAF UANG UNTUK MEMBERDAYAKAN KESEJAHTERAAN MAUQUF 'ALAIH DI YAYASAN DANA SOSIAL AL FALAH (YDSF) SURABAYA

3. Aset wakaf berupa tanah kosong bisa mulai dimanfaatkan dengan pembangunan gedung atau diolah untuk lahan pertanian.

4. Untuk kedepannya, umat Islam dapat lebih mandiri dalam mengembangkan dunia pendidikan tanpa tergantung pada anggaran pendidikan negara yang semakin lama semakin terbatas.

Di dalam Islam, efektivitas merupakan suatu tujuan atau target yang tepat untuk dapat tercapainya kemaslahatan masyarakat serta mempunyai tujuan baik pada dunia dan akhirat. Efektivitas memiliki tujuan yang tepat dalam mencapai tujuan yang diinginkan, dapat menyelesaikan masalah dengan hasil yang telah diperoleh, memiliki kegunaan atau manfaat dari hasil yang diperoleh dan harus dilandasi dengan nilai-nilai kebenaran Islam yaitu bersumber dari Al Qur'an dan As Sunnah.

Dalam mencapai tujuan yang telah ditentukan tersebut haruslah dilandasi dengan nilai-nilai Islam terutama kebenaran, kejujuran, keterbukaan, dan keahlian.Seseorang, organisasi maupun lembaga haruslah selalu bersungguhsungguh dalam melaksanakan sesuatu, terutama dalam mencapai tujuan atau sasaran yang telah ditetapkan. Hal ini sesuai dengan Al Qur'an surat Ash Sharh [94]:7:

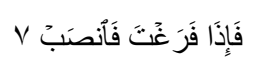

"Maka apabila kamu telah selesai (dari sesuatu urusan), kerjakanlah dengan sungguh-sungguh (urusan) yang lain." (Q.S Ash Sharh [94]:7).
Sumber hukum Islam yang utama adalah berasal dari Al Qur'an dan As Sunnah, maka dari itu kita sebagai umat manusia dianjurkan untuk menjalankan perintah-Nya dan menjauhi laranganNya.Termasuk petunjuk umum tentang amalan wakaf, karena wakaf adalah salah satu golongan perbuatan baik. Berikut Hadits yang diriwayatkan oleh Ibnu Umar r.a (Djunaidi dan Al'Asyhar, 2006:6869):

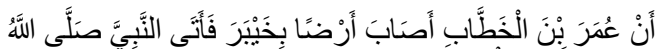

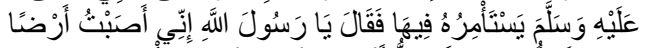

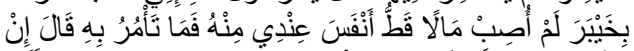

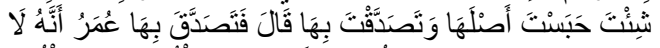

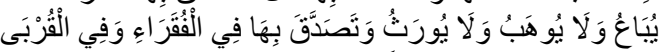

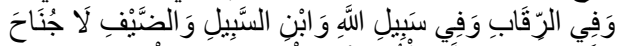

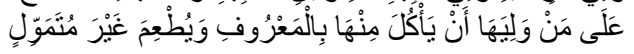

"Sesungguhnya Umar r.a memperoleh sebidang tanah di Khaibar, kemudian menghadap kepada Rasulullah untuk memohon petunjuk. Umar berkata: "Ya Rasulullah, saya mendapatkan sebidang tanah di Khaibar, saya belum pernah mendapatkan harta sebaik itu, maka apakah yang engkau perintahkan kepadaku?" Rasulullah pun menjawab: "Bila kamu suka, kamu tahan (pokoknya) tanah itu, dan kamu sedekahkan (hasilnya). Kemudian Umar melakukan shadaqah, tidak dijual, tidak juga dihibahkan dan juga tidak diwariskan. Berkata Ibnu Umar: "Umar menyediakannya kepada orang-orang fakir, kaum kerabat, budak belian, sabilillah, ibnu sabil dan tamu. Dan tidak mengapa atau tidak dilarang bagi yang menguasai tanah wakaf itu (pengurusnya) makan dari hasilnya dengan cara baik (sepantasnya) atau makan dengan tidak bermaksud menumpuk harta". (HR. Bukhari, Muslim, Abu Dawud, Tirmidzi, Nasi, Ibnu Majah).

Maksud dari hadits diatas tentang Umar bin Khattab mendapatkan sebidang tanah di Khaibar dan meminta nasehat 
Fathona, et al/Jurnal Ekonomi Syariah Teori dan Terapan Vol. 3 No. 1 Januari 2016: 56-69; TERCAPAINYA TINGKAT EFEKTIVITAS WAKAF UANG UNTUK MEMBERDAYAKAN KESEJAHTERAAN MAUQUF 'ALAIH DI YAYASAN DANA SOSIAL AL FALAH (YDSF) SURABAYA

mengenai tanah tersebut kepada Rasulullah Saw. Kemudian Rasulullah saw memerintahkan untuk memanfaatkan tanah tersebut lalu menyedekahkan hasil dari pemanfaatan tersebut kepada orang-orang fakir, para kerabat, para budak, orang-orang yang berjuang di jalan Allah, ibnu sabil, dan para tamu, kemudian pengurusnya dapat memakan hasilnya dengan cara yang makruf.

Dalam pengelolaan wakaf vang yang dinyatakan sah apabila telah terpenuhi rukun atau unsur-unsur sebagai berikut (Dirjen Bimas Islam, 2007:21):

1. Ada wakif (orang yang mewakafkan harta);

2. Ada mauquf bih (benda atau harta yang diwakafkan);

3. Ada mauquf 'alaih (pihak yang diberi wakaf atau peruntukkan wakaf);

4. Ada sighat (pernyataan atau ikrar wakif sebagai kehendak untuk mewakafkan sebagian harta bendanya).

Efektivitas menunjukkan suatu kemampuan perusahaan dalam mencapai sasaran yang telah ditetapkan secara tepat.Pencapaian sasaran yang telah ditetapkan dan ukuran maupun standar yang berlaku mencerminkan suatu perusahaan tersebut telah memperhatikan efektivitas operasionalnya. Terdapat beberapa cara pengukuran terhadap efektivitas, sebagai berikut (Campbell, 1989:121):

1. Pemahaman program Seorang wakif hendaknya memahami program-program yang telah diberikan lembaga perwakafan termasuk dalam pengelolaannya.

2. Ketepatan sasaran

Dapat dilaksanakan menurut ketentuan dan sasaran yang hendak dicapai olehperusahaan serta menjamin ketetapan pelaksanaan tugas sesuai dengan rencana yang telah dibuat.

3. Ketepatan waktu

Perusahaan dapat mengelola secara baik dan tepat waktu supaya para wakif dapat mempercayai lembaga tersebut dan tidak teralihkan pada lembaga wakaf lain.

4. Tercapainya target

Dalam pengelolaannya, lembaga perwakafan haruslah memiliki target salah satunya yaitu dapat mensejahterakan masyarakat dan tercapainya maslahah seperti yang terkandung dalam Al Qur'an dan As Sunnah.

5. Tercapainya tujuan

Tujuan yang dimiliki lembaga wakaf adalah mengurangi kesusahan yang didapat oleh orang yang kurang mampu dan orang yang membutuhkan, serta dapat mensejahterakan masyarakat.

6. Perubahan nyata

Memiliki dampak perubahan nyata yang positif yang dapat diterima oleh lembaga wakaf.

Ekonomi Islam menghendaki semua aktifitas perekonomian dijalankan dengan prinsip kemanfaatan (kemaslahatan) dan meninggalkan yang dapat membawa kerusakan kemudharatan dengan menyeimbangkan aspek dunia dan akhirat,

Maqashid syariah memiliki kemaslahatan yang dijabarkan dalam lima dasar maslahah bagi kehidupan manusia, yakni (Jauhar, 2009):

1. Agama (ad-Din)

Sebagai alasan diwajibkannya berdakwah, bermuamalah secara 
Fathona, et al/Jurnal Ekonomi Syariah Teori dan Terapan Vol. 3 No. 1 Januari 2016: 56-69; TERCAPAINYA TINGKAT EFEKTIVITAS WAKAF UANG UNTUK MEMBERDAYAKAN KESEJAHTERAAN MAUQUF 'ALAIH DI YAYASAN DANA SOSIAL AL FALAH (YDSF) SURABAYA

Islami, dan berjihad jika ada yang berusaha merusak agama.

2. Jiwa (An-Nafs)

Sebagai alasan diwajibkannya pemenuhan kebutuhan pokok untuk hidup (sandang, pangan dan papan) dan pelaksanaan qishash untuk menjaga kemuliaan jiwa manusia.

3. Akal (Al-'Aql)

Sebagai alasan diwajibkannya menuntut ilmu sepanjang hayat, diharamkannya mengkonsumsi benda yang memabukan dan narkoba.

4. Keturunan (An-Nasl)

Sebagai alasan diwajibkannya memperbaiki kualitas keturunan, dan diharamkannya zina serta perkawinan sedarah.

5. Harta (Al-Mal)

Sebagai alasan diwajibkannya pengelola dan megembangkan harta atau kekayaan, sebab dengan kekayaan yang kita miliki membuat kita mampu menjaga empat tujuan yang ada diatasnya. Serta diharamkannya pencurian, suap, bertransaksi riba dan memakan harta orang lain secara bhatil.

\section{METODE PENELITIAN}

\section{Pendekatan Penelitian}

Dalam penelitian ini, pendekatan yang di gunakan adalah kualitatifdeskriptif. Penelitian ini menggunakan strategi studi kasus.

\section{Ruang Lingkup Penelitian}

Ruang lingkup penelitian merupakan suatu batasan studi yang menjelaskan focus studi agar tidak melebar pada masalah yang lain. Penelitian ini yaitu akan fokus pada efektivitas program wakaf vangdalam pemberdayaan kesejahteraan mauquf 'alaihpada Yayasan Dana Sosial Al Falah (YDSF) Surabaya.

\section{Teknik Penentuan Informan}

Penentuan informan dalam penelitian ini menggunakan teknik purposive sampling. Peneliti menggunakan purposive sampling untuk meningkatkan kegunaan informasi yang diperoleh dari sample yang sedikit. Peneliti memilih yang mempunyai pengetahuan banyak dan informatif mengenai fenomena yang sedang diinvestigasi oleh peneliti. Dalam penelitian ini ada pengelola serta beberapa nasabah (wakif) dari Yayasan Dana Sosial Al-Falah Surabaya sebagai informan yang akan diteliti adalah sebagai berikut:

1. Nazhir dari Yayasan Dana Sosial AlFalah Surabaya

2. Wakif Yayasan Dana Sosial Al-Falah Surabaya

3. Mauquf "alaih

\section{Jenis dan Sumber Data}

Jenis data yang akan digunakan dalam penelitian ini adalah data primer dan data sekunder. Berikut ini akan dijelaskan mengenai data primer dan data sekunder:

1. Data primer 
Fathona, et al/Jurnal Ekonomi Syariah Teori dan Terapan Vol. 3 No. 1 Januari 2016: 56-69; TERCAPAINYA TINGKAT EFEKTIVITAS WAKAF UANG UNTUK MEMBERDAYAKAN KESEJAHTERAAN MAUQUF 'ALAIH DI YAYASAN DANA SOSIAL AL FALAH (YDSF) SURABAYA

Data primer merupakan data utama yang berasal dari hasil wawancara mendalam dan observasi langsung di lapangan.Data tersebut dikumpulkan dengan metode wawancara dimana metode ini memungkinkan peneliti bertatap muka langsung dengan informan untuk menggali informasi dengan lebih mendalam sehingga dapat dipertanggung jawabkan validitas datanya.

2. Data sekunder

Data sekunder seperti literatur dan menunjang hasil penelitian berupa dokumen baik berupa media cetak maupun elektronik.

\section{Teknik Pengumpulan Data}

Pengumpulan data adalah prosedur yang sistematis dan standar untuk memperoleh data yang diperlukan, diantaranya adalah:

\section{Persiapan awal}

Persiapan awal mencakup pengurusan surat ijin untuk melakukan survei pendahuluan dan melakukan peninjauan awal terhadap objek penelitian. Persiapan awal ini dapat digunakan sebagai acuan dan masukan dalam memulai penulisan skripsi ini. Pada tahap persiapan ini, surat ijin penelitian skripsi diurus secara formal pada bagian akademik Fakultas Ekonomi dan Bisnis Universitas Airlangga sebagai pelengkap untuk memasuki Yayasan Dana Sosial Al-Falah Surabaya yang akan diteliti.

2. Proses saat di lokasi atau objek penelitian
Pada tahap ini peneliti telah memasuki objek penelitian yaitu menemui pengurus Yayasan Dana Sosial Al-Falah Surabaya berdasarkan kesepakatan yang telah dibuat sebelumnya dengan membawa surat ijin penelitian secara formal dari Fakultas Ekonomi dan Bisnis Universitas Airlangga sebagai pelengkap. Setelah itu dilakukan kunjungan untuk menjelaskan maksud dan tujuan penelitian kepada pengurus Yayasan Dana Sosial Al-Falah Surabaya yang dituju kemudian dilakukan observasi langsung pada pengurus Yayasan Dana Sosial Al-Falah.

3. Saat pengumpulan data Ini adalah tahapan pengumpulan data primer yang diperoleh melalui wawancara serta observasi secara mendalam dengan pengurus Yayasan Dana Sosial Al-Falah Surabaya, wakif, dan mauquf 'alaih sebagai informan yang dilakukan secara terbuka dan berkala. Wawancara digunakan untuk mendapatkan data atau informasi mengenai efektivitas program wakaf uang dalam pemberdayaan kesejahteraan mauquf 'alaihpada Yayasan Dana Sosial Al Falah (YDSF) Surabaya

Sedangkan untuk data sekunder dikumpulkan dengan cara mencari literatur atau buku-buku yang terkait dengan wakaf ataupun wakaf vang; hasil penelitian yang diperoleh dengan membaca artikel dan jurnal yang berkaitan, browsing internet, dan skripsi di ruang baca Fakultas Ekonomi dan Bisnis Universitas Airlangga; serta dokumen yang 
Fathona, et al/Jurnal Ekonomi Syariah Teori dan Terapan Vol. 3 No. 1 Januari 2016: 56-69; TERCAPAINYA TINGKAT EFEKTIVITAS WAKAF UANG UNTUK MEMBERDAYAKAN KESEJAHTERAAN MAUQUF 'ALAIH DI YAYASAN DANA SOSIAL AL FALAH (YDSF) SURABAYA

berkaitan yang diperoleh dari Yayasan Dana Sosial Al Falah Surabaya.

\section{Teknik Analisis Data}

Setelah itu dalam analisis setelah di lapangan, penulis menggunakan teknik analisis lapangan model Miles dan Hubernan (1992) yang terdiri dari 3 tahap teknik analisis yaitu:

1. Reduksi data

Reduksi data adalah proses pemilihan, pemusatan perhatian pada penyederhanaan, pengabstrakan dantransformasu data kasar yang muncul dari catatancatatan tertulis di lapangan (Miles dan Huberman, 1992:16). Dalam penelitian ini hasil wawancara diperoleh melalui wawancara yang dilakukan kepada Yayasan Dana Sosial Al-Falah Surabaya.Selanjutnya peneliti mengarahkan, membuang yang tidak perlu dan mengorganisir data hingga diperoleh data-data yang dibutuhkan dalam penelitian.

2. Penyajian data

Setelah direduksi, langkah selanjutnya adalah menyajikan data.Dalam penelitian kualitatif penyajian data bisa dilakukan dalam bentuk uraian singkat, bagan, hubungan antar kategori dan sejenisnya.Tujuannya dalah untuk memudahkan membaca dan menarik kesimpulan.Peneliti menyajikan data penelitian ini dalam bentuk teks naratif, bagan, dan tabel.

3. Kesimpulan dan verifikasi
Dalam tahap ini, peneliti membuat proposi yang terkait dengan prinsip logika, mengangkatnya sebagai temuan penelitian, kemudian dilanjutkan dengan mengkaji secara berulang-ulang terhadap data yang ada, pengelompokan data yang telah dibentuk, dan proposisi yang telah dirumuskan. Langkah selanjutnya adalah melaporkan hasil penelitian secara lengkap dengan temuan baru yang berbeda dengan temuan yang sudah ada.

\section{Teknik Keabsahan Data}

Penelitian ini menggunakan metode triangulasi sumber untuk mengecek data yang diperoleh dari informan mengenai efektivitas program wakaf vang dalam pemberdayaan kesejahteraan mauquf 'alaihpada Yayasan Dana Sosial Al Falah (YDSF) Surabaya. Peneliti menggunakan teknik pengumpulan data yang berbeda sumber, antara lain bersumber dari nadzir YDSF sebanyak 2 orang, wakif sebanyak 2 orang, dan mauquf 'alaih sebanyak 3 orang. Total narasumber adalah 7 orang.

\section{HASIL DAN PEMBAHASAN}

Efektivitas secara sederhana dapat dipahami sebagai tingkat keberhasilan suatu kebijakan atau program dalam usahanya untuk mencapai tujuan sesuai dengan perencanaan yang diinginkan sehingga menghasilkan dampak yang sesuai dengan harapan.Efektivitas seringkali dikaitkan dengan efisiensi, namun pada 
Fathona, et al/Jurnal Ekonomi Syariah Teori dan Terapan Vol. 3 No. 1 Januari 2016: 56-69; TERCAPAINYA TINGKAT EFEKTIVITAS WAKAF UANG UNTUK MEMBERDAYAKAN KESEJAHTERAAN MAUQUF 'ALAIH DI YAYASAN DANA SOSIAL AL FALAH (YDSF) SURABAYA

penjelasannya efektivitas memiliki makna yang berbeda dengan efisiensi. Drucker (2001:15) menyatakan dimana efektivitas pada hakikatnya melakukan sesuatu yang benar (doing the right thing) sedangkan efisiensi adalah melakukan dengan benar (doing things right). Disini terlihat bahwa Drucker menekankan konsep efektivitas lebih pada pencapaian sasaran sesuai dengan yang direncanakan.Sedangkan efisiensi lebih menekankan bagaimana sebaiknya dilakukan.

Sementara itu menurut Arens dan Loebbecke (2001:25) menyatakan bahwa "Effectiveness refers to accomplishment of objective, whreas affieciency refers to the resource use to achieved those objecktives". Pernyataan tersebut jelas bahwa orientasi efektivitas ada pada pencapaian tujuan dari suatu program/kebijakan.Yakni seberapa berhasilkah suatu program/kebijakan dapat mencapai tujuan.Sedangkan Tyson dan Jackson (2008:18) menjelaskan bahwa efektivitas dapat di definisikan sebagai kecakapan untuk menyesuaikan diri terhadap lingkungan yang berubah seerta yang menjadi dasar efektivitas adalah integrasi.Jadi apabila dikaitkan dengan efektivitas kebijakan, tentunya melalui program atau kebijakan diharapkan masalah-masalah yang terjadi di masyarakat dapat berhasil direduksi menyesuaikan dengan keinginan masyarakat yang normatifnya tentu tanpa adanya suatu permasalahan di dalam lingkungan masyarakat.Atau jika di nilai dari sudut pandang masyarakat diharapkan melalui pengambilan keputusan denngan adanya kebijakan/program maka masyarakat mampu menyesuaikan dengan kondisi lingkungan yang menjadi permasalahan yang tidak bisa dihindari oleh masyarakat. Efektivitas secara sederhana dapat dipahami sebagai tingkat keberhasilan suatu kebijakan atau program dalam usahanya untuk mencapai tujuan sesuai dengan perencanaan yang diinginkan sehingga menghasilkan dampak yang sesuai dengan harapan.

Tingkat keberhasilan dan efektivitas dalam penelitian ini digunakan ukuran (indikator) yang dirumuskan oleh Campbell (1989:121). Apabila dikaitkan dengan teori tersebut maka hasilnya dapat disajikan dari ke 7 informan yang telah di wawancara sebelumnya adalah sebagai berikut:

1. Pemahaman program; $85 \% \quad 16$ informan) memahami program yang ada.

2. Ketepatan sasaran; $100 \%$ (7 informan) telah memenuhi sasaran.

3. Ketepatan waktu; $71 \%$ (5 informan) menjawab tidak memakan waktu yang lama sedangkan sisanya menjawab pengerjaannya mengulurulur waktu.

4. Tercapainya target; $85 \%$ (6 informan) telah menjawab target yang direncanakan untuk kemaslahatan berdampak positif. 
Fathona, et al/Jurnal Ekonomi Syariah Teori dan Terapan Vol. 3 No. 1 Januari 2016: 56-69; TERCAPAINYA TINGKAT EFEKTIVITAS WAKAF UANG UNTUK MEMBERDAYAKAN KESEJAHTERAAN MAUQUF 'ALAIH DI YAYASAN DANA SOSIAL AL FALAH (YDSF) SURABAYA

5. Tercapainya tujuan; $100 \%$ (7 informan) menjawab bahwa tujuan yang dicapai sudah sangat membantu dan sudah diterima oleh mauquf "alaih.

6. Perubahan nyata; $85 \%$ (6 informan) telah menjawab perubahan yang terjadi memiliki dampak positif.

Tingkat efektivitas tersebut digabungkan dengan indikator maqashid syariah, maka hasilnya sebagai berikut:

1. Agama; $85 \%$ (6 informan) telah menjawab rutin beribadah.

2. Jiwa; $100 \%$ (7 informan) telah menjawab selalu membiasakan shalat berjama'ah dan mengikuti pengajian di masjid ataupun di rumah supaya mendapatkan ketenangan jiwa.

3. Akal; $100 \%$ (7 informan) telah menjawab memberikan pendidikan agama di lingkungan rumah maupun sekolah, serta memberikan pengarahan kepada anak untuk dapat menutup aurat.

4. Keturunan; $100 \%$ (7 informan) telah menjawab selalu membimbing anak supaya bisa menjadi lebih baik serta mendapatkan bekal dunia dan akhirat.

5. Harta; $71 \%$ (5 informan) telah menjawab memberikan biaya khusus untuk bersedekah.

Hasil akhir menunjukkan bahwa dari kedua indikator tersebut adalah program wakaf uang yang telah dijalankan oleh Yayasan Dana Sosial Al Falah (YDSF) Surabaya pada dasarnya telah memenuhi keefektivitasan yang dapat mendorong tujuan dari maqashid syariah yaitu kebahagiaan dunia dan akhirat.Dengan kata lain efektivitas di Yayasan Dana Sosial Al Falah (YDSF) Surabaya dapat mendorong pemberdayaan para mauquf 'alaih dengan program wakaf vang yang telah ditawarkan. Kesimpulan telah menunjukkan bahwa efektivitas program wakaf vang di YDSF dapat mendorong pemberdayaan kesejahteraan para mauquf 'alaih

\section{v. SIMPULAN}

Berdasarkan pembahasan yang telah dijelaskan, maka didapatkan kesimpulannya sebagai berikut:

1. Hasil kesimpulan kedua indikator tersebut adalah program wakaf uang yang telah dijalankan oleh Yayasan Dana Sosial Al Falah (YDSF) Surabaya pada dasarnya telah memenuhi keefektivitasan yang dapat mendorong tujuan dari maqashid syariah. Dengan kata lain Yayasan Dana Sosial Al Falah (YDSF) Surabaya bisa mendorong maqashid syariah dengan program yang telah ditawarkan (wakaf uang). Dengan penelitian ini kesimpulan telah menunjukkan bahwa efektivitas dapat mendorong kesejahteraan maqashid syariah.

Saran

1. Perwakafan di Indonesia masih dikelola secara tradisional (benda tidak bergerak: tanah dan bangunan). Berbeda dengan pengelolaan wakaf 
Fathona, et al/Jurnal Ekonomi Syariah Teori dan Terapan Vol. 3 No. 1 Januari 2016: 56-69; TERCAPAINYA TINGKAT EFEKTIVITAS WAKAF UANG UNTUK MEMBERDAYAKAN KESEJAHTERAAN MAUQUF 'ALAIH DI YAYASAN DANA SOSIAL AL FALAH (YDSF) SURABAYA

di beberapa negara Islam lainnya yang telah memiliki manajemen pengelolaan wakaf yang tidak lagi terfokus pada sarana peribadatan tetapi ruang lingkupnya sudah cukup luas yaitu seluruh harta kekayaan baik yang bergerak maupun tidak bergerak, yang berwujud maupun tidak berwujud.

2. Bagi Yayasan Dana Sosial Al Falah (YDSF) Surabaya supaya semakin mengembangkan program-program yang sudah ada supaya masyarakat yang mendapatkan hasilnya semakin luas dan tercapainya maslahah.

3. Bagi penelitian selanjutnya, agar dilakukan penelitian yang lebih mendalam mengenai program wakaf khususnya wakaf uang agar dapat dikembangkan dengan melakukan penelitian di lembaga perwakafan di seluruh wilayah Jawa Timur.

\section{DAFTAR PUSTAKA}

Al Quran Dan Terjemahnya. 2012. Departemen Agama Republik Indonesia

Anshori, Abdul Ghafur. 2005. HukumDan Praktik Perwakafan Indonesia. Pilar Media: Jakarta.

Antonio,Muhammad

Syafi'i. 2006.Pengelolaan wakaf Secara Produktif, dalam Achmad Junaidi, Menuju Era Wakaf Produktif.Jakarta: Mitra Abadi Press.
Asy-Syarbini Al Katib, Muhammad, Mugni Al Muhtaj Syarh Al Minhaj. Mustafa Halabi: Kairo.

Departemen Agama Ri. 1981. Wakaf Tanah Potensi Dan Masalahnya. Dirjen Bimas Dan Urusan Haji: Jakarta.

Drucker, P.F.2001. Managing In Time of Great Change. Penguin books: New York.

Campbell, Jp 1989. Riset Dalam Efektivitas

Organisasi, Terjemahan Salut

Simamora. Jakarta: Erlangga.

Lubis, M. Yamin Dan Abd. Rahim Lubis. 2010. Hukum Pendaftaran Tanah.

Penerbit Mandar Maju: Bandung.

Loebbecke, Arens, Alvin A, dan James K. 2001. Auditing Suatu Pendekatan Terpadu. Buku Satu: Jakarta.

Moelong, Lexy J. 2004. Metodologi Penelitian Kualitatif. PT. Remaja: Bandung.

Sabiq, Sayyid. 1983. Fiqh As Sunnah. Dar Al Fikr: Beirut.

Siba'i, Mustafa dan Muhsin. 2004. Hukum Islam dan Perundang-undangan. Jakarta: Bulan Bintang

Tyson, Shaun dan Tony Jackson. 2008. Perilaku Organisasi. Yogyakarta Yin, Robert. 1996. Studi Kasus, Desain Dam Metode. PT. Raja Grafindo Persada: Jakarta. 